\title{
INTOLERÂNCIA RELIGIOSA: O DISCURSO ETNOCÊNTRICO DA IGREJA UNIVERSAL CONTRA AS RELIGIÕES DE MATRIZ AFRICANA
}

Giovani Zanirati ${ }^{\mathrm{i}}$

\begin{abstract}
Resumo: A presente pesquisa tem como objetivo apresentar o discurso etnocêntrico da Igreja Universal do Reino de Deus, liderada pelo Bispo Edir Macedo, contra as religiões de matriz africana. Diante essa controvérsia questão existe, desde o período colonial, um histórico de opressão e de violência contra a população negra. Dessa forma, ao aproveitar este cenário, o Bispo Edir Macedo soube transformar a IURD em um dos maiores fenômenos religiosos do mundo, contribuindo para a desqualificação do imaginário social dos adeptos das religiões de origem africana no Brasil. Por fim, para realizar a pesquisa, utilizo fontes bibliográficas de grande valor para a compreensão do presente cenário.
\end{abstract}

Palavras chave: Etnocentrismo; intolerância religiosa; Igreja Universal; Edir Macedo; África.

\section{RELIGIOUS INTOLERANCE: UNIVERSAL CHURCH OF THE KINGDOM OF GOD ETHNOCENTRIC SPEECH AGAINST AFRICAN-DERIVED IN BRAZIL}

\begin{abstract}
The present research aims to introduce the Universal Church of the Kingdom of God ethnocentric speech, which is led by the Bishop Edir Macedo, against religions form African headquarters. Before this controversial question there is, since colonial period, a history inequality, racism, oppression, intolerance and violence against black population. This way, by taking vantage of this scenario, Bishop Edir Macedo knew how to transform the IURD (UCGK) in one of the biggest religious phenomena of the world, contributing to the disqualification of African origin religions' adepts' social imaginary in Brazil. Finally, to perform the research, I make use of great value bibliographic sources to the comprehension of the present scenario.
\end{abstract}

Keywords: Ethnocentrism; religious intolerance; Universal Church; Edir Macedo; Africa.

\section{Introdução}

A pesquisa tem como objetivo apresentar o etnocentrismo presente no discurso de Edir Macedo e da Igreja Universal do Reino de Deus (IURD) contra as religiões de matriz africana no Brasil. A IURD é, sem dúvidas, um dos principais fenômenos religiosos das últimas décadas e parte desse sucesso refere-se ao conflito espiritual contra as religiões de matriz africana, como o Candomblé e a Umbanda. A pesquisa, dessa forma, é dividida em quatro partes. Na primeira parte, para situar o leitor na discussão, apresento o conceito de etnocentrismo, tendo como referências as pesquisas de importantes intelectuais, como Roberto da Matta, Roque de Barros Laraia e Everardo P. Guimarães Rocha. No segundo momento, utilizo o polêmico livro Orixás, Caboclos e Guias: Deuses ou demônios? de Edir Macedo, relançado em 2019, para 
contextualizar os ataques proferidos contra a Umbanda e o Candomblé. Na sequência, pretendo expor o histórico de intolerância contra a população negra (principalmente em aspectos religiosos) no Brasil. Por fim, relaciono essas problemáticas (o discurso da IURD e os ataques sofridos pelas religiões de matriz africana) com a construção da democracia neoliberal, que mantém diversas mazelas do período escravagista.

\section{O que é etnocentrismo?}

A manifestação de um presidente da República é habitualmente marcada de grande repercussão nacional e internacional. Por consequência, ao dizer que os povos indígenas encontram-se em processo de evolução, o presidente Jair Bolsonaro (sem partido) trouxe a tona debates antigos, porém presentes na sociedade sobre o etnocentrismo e a pluralidade cultural. Na ocasião, ele disse: "Com toda a certeza, o índio mudou. Está evoluindo. Cada vez mais o índio é um ser humano igual a nós. Então, fazer com que o índio cada vez mais se integre à sociedade e seja realmente dono de sua terra indígena. É isso que nós queremos". ii A declaração se tronou alvo de polêmica. A Coordenadora da Articulação dos Povos Indígenas, Sônia Guajajara, candidata à vice-presidência pelo Partido Socialista e Liberdade (PSOL), em 2018, anunciou, em uma rede social, que pretendia ir à justiça contra o presidente por crime de racismo. ${ }^{\text {iii }}$

É importante lembrar que a declaração de Bolsonaro não pode ser tratada de forma isolada porque em diversas oportunidades, ele manifestou-se contra os povos indígenas. Em 2017, em uma palestra no Clube Hebraica, prometeu que, caso fosse eleito presidente, não haveria demarcação de terras indígenas ${ }^{\text {iv }}$. Como presidente anunciou que tentaria rever a reserva indígena Raposa Serra Sol, em Roraima, alegando ser uma terra rica e produtiva. A discussão, contudo, é antiga. Em 2008, em uma Sessão na Câmara dos Deputados, ele polemizou com Jecinaldo Sateré Maué, da Coordenação das Organizações Indígenas da Amazônia Brasileira. Em audiência pública para discutir sobre a demarcação da terra, Jecinaldo atirou um copo d'água em Bolsonaro. Bolsonaro, por sua vez, passou a sessão defendendo os fazendeiros e a não demarcação das terras; além disso, considerou Jecinaldo incapaz de debater o tema. "É um índio que está a soldo aqui em Brasília, veio de avião, vai agora comer uma costelinha de porco, tomar um chope, provavelmente um uísque, e quem sabe telefonar para alguém para a noite sua ser mais agradável. Esse é o índio que vem falar aqui de reserva indígena. Ele devia ir comer um capim ali fora para manter as suas origens" disse Bolsonarov".

A postura de Bolsonaro em caracterizar uma comunidade como atrasada e, também, usar termos pejorativos como "comer um capim para manter as origens" são marcadas por preconceito. Ele ao utilizar o próprio modo de vida como referência para classificar o "outro" reforça uma divisão hierárquica entre grupos diferentes (nós x eles). Isto é uma característica do etnocentrismo. 
Etnocentrismo é uma visão do mundo onde o nosso próprio é tomado como centro de tudo e todos os outros são pensados e sentidos através dos nossos valores, nossos modelos, nossas definições do que é a existência. No plano intelectual, pode ser visto como a dificuldade de pensarmos a diferença; no plano afetivo, como sentimentos de estranheza, medo, hostilidade, etc. Perguntar sobre o que é etnocentrismo é, pois, indagar sobre um fenômeno onde se misturam tantos elementos intelectuais e racionais quanto elementos emocionais e afetivos. (ROCHA, 1988, p.5)

O etnocentrismo pode ser entendido como um conceito universal. De acordo com LARAIA (2001, p.38) é comum a crença de que a própria sociedade é o centro da humanidade, ou mesmo a única expressão. É necessário, contudo, deixar manifesto a forma como esse conceito foi, e ainda é, tratado pelos ocidentais ao longo dos últimos séculos. Por exemplo: os europeus, a partir das Grandes Navegações e a descoberta do Novo Mundo (final século XV e início do século XVI), utilizaram o etnocentrismo como um dos argumentos para obter o controle das novas regiões. Os povos do Novo Mundo (os não ocidentais) eram normalmente caracterizados pelos colonizadores como "selvagens sem alma" porque na concepção dos europeus era inadmissível uma forma de vida diferente (hábitos alimentares, vestimentas, aparências, crenças religiosas). Esse tipo de discussão, que envolveu missionários, administradores e filósofos, se perpetuou ao longo do tempo. No Brasil, por exemplo, uma das principais missões de Portugal foi catequizar os nativos em meio ao período conturbado da Reforma Protestante e da Contra-Reforma. De acordo com CUNHA (2017) os Jesuítas foram os principais responsáveis por esse procedimento, ao adotar táticas pedagógicas para associar as crenças indígenas ao catolicismo.

\section{Evolucionismo social, etnocentrismo e relativismo.}

A discussão sobre etnocentrismo fica evidente a partir da segunda metade do século XIX e início do século XX. De acordo com LAPLANTINE (2003) foi apenas nesse período que as concepções de homem e de cultura começaram a mudar. Entra em cena a Antropologia (Social ou Cultural). A disciplina tem como uma das características apresentar novas metodologias de estudo para compreender as diferenças entre os seres humanos. O processo, contudo, é longo, ficando impossível debater sobre as principais escolas, os autores e suas contribuições. Mas notem como a primeira escola antropológica, a evolucionista, apresenta características etnocêntricas, ainda presentes na sociedade contemporânea ${ }^{\mathrm{vi}}$

A escola evolucionista, segunda metade do século XIX, tem como característica uma concepção linear da história da humanidade, baseando-se na comparação entre os povos de diferentes localidades (ocidentais e não ocidentais). A escola foi influenciada por importantes transformações sociais como, por 
exemplo, o neocolonialismo, onde grandes potências europeias como a Inglaterra, a França, a Bélgica, a Holanda partilharam países da Ásia, da África e da Oceania com o propósito de explorar as riquezas naturais e a mão de obra dos nativos. Os principais nomes da escola: Lewis Henry Morgan (1818-1841), Edward Burnett Tylor (1832-1917) e James George Frazer (1854-1941) enviaram diversos administradores às regiões exploradas para construir uma rede de informações com os nativos. A partir do material recolhido, os antropólogos apontaram que os povos não ocidentais como, por exemplo, os aborígenes australianos, mesmo sendo contemporâneos, representavam as características dos antepassados dos ocidentais. Ou seja, independentes da época e da região, os povos percorrerem o mesmo caminho histórico; esse caminho, por sua vez, apresenta diversas etapas até, por fim, alcançar ao estágio máximo, a civilização. Para facilitar a discussão, apresento como exemplo um resumo do trabalho de Morgan (2005). O autor dividiu o desenvolvimento da humanidade em etapas lentas, quase imperceptíveis, e conectadas: a selvageria, a barbárie e a civilização. A duas primeiras eram fragmentadas em três etapas: inferior, intermediário e superior. As invenções e as descobertas, o desenvolvimento da família e, principalmente, da propriedade privada seriam os principais fatores que determinam esse processo evolutivo.

Quais os problemas da escola evolucionista? As comparações entre os povos eram realizadas através da realidade social do próprio antropólogo (Morgan dos Estados Unidos; Frazer e Tylor da Inglaterra). Ou seja: a tecnologia, o governo, a sociedade patriarcal, a religião monoteísta, a vestimenta, e os diversos costumes habituais. Dessa forma ao criarem um processo histórico linear dividido em diversas etapas, a sociedade ocidental era considerada o estágio máximo; enquanto isso, os povos não ocidentais eram considerados como inferiores.

Explicando melhor, a Inglaterra do século XIX era, de fato, contemporânea dos aborígenes australianos, por exemplo. Ao afirmar que todas as formações sociais humanas tinham origens remotas e caminhavam no mesmo sentido, na direção do progresso, os evolucionistas pensavam que os australianos haviam parado num estádio "primitivo" e os ingleses avançado para um estágio "civilizado". (ROCHA, 1988, p.13).

Não existia por parte dos estudiosos maior interesse em compreender uma sociedade através de seus aspectos mais específicos, pois a principal forma de obter o material ocorreu através de relatórios realizados 
por administradores. Os evolucionistas realizaram poucos trabalhos etnográficos. Dessa forma, ficaram conhecidos como "antropólogos de gabinete". Tylor (2005), por exemplo, defendia os relatos dos administradores como evidência científica e verdadeira porque existia similaridade nos materiais apresentados. Essa metodologia seria bastante criticada por antropólogos posteriores.

O caráter etnocêntrico da escola fica evidente ou, conforme menciona LARAIA (2001), a escala evolutiva apresenta um processo discriminatório, que privilegia as culturas europeias, ou seja, um período onde etnocentrismo e ciência marchavam então de mãos juntas. O antropólogo Roberto da Matta também é um dos críticos da metodologia evolucionista.

Assim, embora tivessem sido os evolucionistas os primeiros a vislumbrar as enormes potencialidades do método comparativo, eles não puderam aproveitar totalmente tais potencialidades, porque comparavam costume com costume, em vez de comparar, como fazemos hoje, o costume com o contexto onde ele aparece como tal e, somente depois desta operação, o costume desta sociedade com o de uma outra. (DA MATTA, 1997, p.90).

Obviamente o choque cultural é comum entre os povos. Estamos acostumados aos nossos hábitos e, dessa modo, podemos estranhar comunidades diferentes. O choque ocorre porque, ao longo dos anos e das relações sociais, construímos uma identidade.

A nossa herança cultural, desenvolvida através de inúmeras gerações, sempre nos condicionou a reagir depreciativamente em relação ao comportamento daqueles que agem fora dos padrões aceitos pela maioria da comunidade. Por isto, descriminamos o comportamento desviante. (LARAIA, 2001, p.35).

Porém a nossa cultura, além de não ser a única, não pode ser interpretada como a "melhor" ou “evoluída” em relação às demais. Essas visões, na verdade, abrem um leque de discussões: "o que é seria melhor”? "o que é evoluída”? "quais os critérios estabelecidos para definir se uma sociedade é evoluída ?”. Franz Boas (2005), importante antropólogo alemão do início das primeiras décadas do século XX, diferentemente dos evolucionistas, pensava que cada sociedade apresentava capacidade de construir a própria história e a própria cultura; por este motivo, a partir do autor, cultura começa a ser tratada de forma diversificada. Aos poucos começou a ser desconstruída a ideia do Ocidente como um guia para os nãos ocidentais; e os nãos ocidentais como "museus vivos" para os ocidentais. 
Porém para DA MATTA (1997) e ROCHA (1988), a escola funcionalista foi mais eficaz nesse processo de relativização. A escola é associada aos trabalhos de Bronislaw Malinowski (1844-1942) e Radcliffe-Brown (1881- 1955). Os autores apontam o caminho para o processo de relativização da disciplina: o rompimento com a história, a compreensão de uma sociedade a partir da sua própria perspectiva e o trabalho de campo. ROCHA (1994) destaca que, a partir de Radcliffe-Brown, ocorreu um rompimento da disciplina com a história. Não existia mais a necessidade de estudar uma sociedade pelo passado porque a preocupação com a história é, antes de tudo, tipicamente ocidental. Por consequência, as hierarquias entre as sociedades avançadas e atrasadas, e o Ocidente como exemplo a ser seguido pelos demais são desconstruídas. A sociedade do "outro" passa a ser compreendida a partir da própria realidade. O trabalho de campo é outra importante metodologia adotada pelos antropólogos para coletar dados e construir uma reflexão sobre a sociedade estudada. Malinoswki não foi o primeiro pesquisador a realizar essa metodologia. Mas, em 1922, publicou a obra Os Argonautas do Pacífico Ocidental, um clássico das Ciências Humanas, após 31 meses de convivência com os nativos de um arquipélago formado pelas Ilhas Trobriand. De acordo com DA MATTA (1997), o trabalho de campo realizado por Malinowski foi fundamental porque a Antropologia deixaria de colecionar curiosidades históricas e passaria a atuar como uma verdadeira ciência da sociedade. Em sua estadia, Malinowski pesquisou um evento chamado "Kula", onde os nativos trocavam presentes (colares e braceletes) entre os moradores das ilhas vizinhas. ROCHA (1988) considera que, a partir desse evento, Malinowski realizou uma comparação relativizadora. Ao invés de tratar o significado dos costumes do "outro" pela perspectiva ocidental, ele fez o contrário: comparou os objetos de Trobriand com os da Coroa do Império britânico, de acordo com seu respectivo contextos.

Esquematicamente falando, a comparação de Malinowski foi dos braceletes e colares do Kula com seu significado na sociedade trobriandesa versus jóias da Coroa Britânica com seu significado na sociedade inglesa. Comparou relativizando o "eu" e o "outro". (Ibidem, p.30).

O processo de relativizar foi muito importante para o crescimento e autonomia da Antropologia. MENESES (1999) aponta as consequências do relativismo cultural: enquanto o etnocentrismo toma os costumes dos "outros" como bizarros e atrasados, o relativismo contribui para uma concepção oposta, onde 


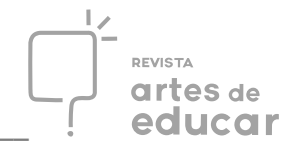

os comportamentos fazem parte de um contexto social ainda pouco compreendido por "nós"; cada cultura deve ser estudada a partir da perspectiva dos atores sociais presentes na comunidade, sem o objetivo de modificá-la ou “ajudá-la” a “evoluir”. Roberto Cardoso de Oliveira (2000) considera que a relativização é uma atitude eminentemente antropológica, graças a qual o pesquisador logra escapar da ameaça do etnocentrismo.

\section{Novas discussões: o discurso da Igreja Universal do Reino de Deus}

O estranhamento em relação ao "outro" não pode ser entendido como uma característica existente apenas entre povos que se encontram distante. Em diversas situações, colegas (trabalho, faculdade, escola) ou, até mesmo, moradores de um mesmo bairro podem apresentar características diversas. As relações nas grandes cidades são heterogêneas, com grupos diversos coexistindo com maior ou menor grau de tensão. Portanto é possível buscar diversos exemplos de etnocentrismo em nossa sociedade. Um deles é a intolerância contra as religiões de matriz africana. Os adeptos de crenças como o Candomblé e a Umbanda, por exemplo, ainda sofrem com a perseguição e o preconceito. Um dos principais casos de perseguição e de preconceito está relacionado aos ataques dos neopentecostais.

O pentecostalismo, por sua vez, é um fenômeno religioso que chegou ao Brasil no início do século $\mathrm{XX}$, com origem nos Estados Unidos. ${ }^{\text {vii }} \mathrm{A}$ chamada terceira onda do pentecostalismo, o neopentecostalismo, representa a principal expansão dos evangélicos no Brasil.viii

Conforme os Censos Demográficos do IBGE, os evangélicos perfaziam apenas $2,6 \%$ da população brasileira na década de 1940. Avançaram para 3,4\% em 1950, $4 \%$ em 1960, 5,2\% em 1970, 6,6\% em 1980, 9\% em 1991 e 15,4\% em 2000, ano em que somava 26.184.941 pessoas (MARIANO, 2004, p.121).

Nos dados divulgados pelo Censo de 2010, os evangélicos passaram para 22,2\% da população, que corresponde a um aumento de 16 milhões de pessoas (de 26, 2 milhões para 42,3 milhões); o catolicismo, por sua vez, apresentou queda no número de adeptos (de 73,6\% em 2000 para 64,6\% em 2010). ${ }^{\text {ix }}$ De acordo com a pesquisa Datafolha, em 2019, os evangélicos correspondem a 31\% da população brasileira, enquanto a população católica corresponde a $50 \%{ }^{\mathrm{x}}$ 
Em termos teológicos, os neopentecostais normalmente caracterizam-se pela Guerra espiritual contra o Diabo e pela difusão da Teologia da prosperidade. Para conquistar um número maior de fiéis, o neopentecostalismo rompeu com parte do tradicionalismo pentecostal e se adaptou as dinâmicas da sociedade.

De modo que seus fiéis foram liberados para vestir roupas da moda, usar cosméticos e demais produtos de embelezamento, frequentar praias, piscinas, cinemas, teatros, torcer para times de futebol, praticar esportes variados, assistir a televisão e vídeos, tocar e ouvir diferentes ritmos musicais. Práticas que, nos últimos anos, também foram sendo paulatinamente permitidas por igrejas pentecostais das vertentes precedentes, com exceção da Deus é Amor, que manteve incólume a velha rigidez ascética. Em todas as vertentes permanece, porém, a interdição ao consumo de álcool, tabaco e drogas e ao sexo extraconjugal e homossexual. (Ibidem, p.124).

A Igreja Universal do Reino de Deus (IURD), principal representante do neopentecostalismo brasileiro, fundada por Edir Macedo ${ }^{\text {xi }}$ em 1977, pode ser considerada um dos maiores fenômenos religiosos dos últimos 50 anos. Além do campo religioso e demográfico, a IURD se faz presente nos campos políticos partidários e midiáticos, atingindo diversas camadas da sociedade.

Desde o início do trabalho, Edir Macedo adotou diversas medidas para o crescimento da igreja: uso da mídia (televisão e rádio), a guerra espiritual contra o diabo e os demônios; demônios associados na maioria das vezes às religiões de matriz africana, distinguindo-se do pensamento das demais igrejas pentecostais $(\mathrm{ORO}, 1997)$ e a teologia da prosperidade,. O Bispo ainda exerce uma liderança carismática com um discurso capaz de se adaptar as realidades da sociedade.

Vou trabalhar com o confronto espiritual, mas cabe uma observação sobre a teologia da prosperidade. A teologia da prosperidade reforça a concepção que os religiosos devem buscar a riqueza, o conforto e o dinheiro para obterem uma vida digna e feliz. Ou seja, significa uma mudança importante em relação aos ideais de desapego aos bens materiais e a necessidade de buscar uma recompensa pós-morte, comum entre os cristãos. A "recompensa", nesse caso, deve ser obtida em vida. O fiel precisa seguir o caminho apresentado pela IURD. Além disso, Macedo reforça a necessidade da iniciativa individual de cada fiel. Mas se, eventualmente, o fiel na missão, Macedo apresenta um culpado (ou pelo menos um dos culpados): o diabo e os demônios. A Igreja Universal, dessa forma, realiza um discurso onde valoriza o esforço individual de cada seguidor (empreendedor de si mesmo) em meio a uma guerra espiritual entre Deus e o Diabo. Diversos outros problemas sociais como a violência e a corrupção também estariam associados aos demônios. Macedo conseguiu recuperar uma imagem do Diabo que é central na história do Cristianismo, porém, ele lhe dá renovadas forças (...) em meio a grandes crises sociais (SOUZA, 2000, p. 105). O Bispo, durante a pandemia do coronavírus (Covid-19), chegou a atribuir a crise a Satanás. ${ }^{\text {xii }}$ Para completar o cenário, o Bispo precisa apresentar os canais de atuação do Diabo: as religiões de matriz 
africana (em maior escala do que o catolicismo e o espiritismo) representam, segundo Edir Macedo, uma poderosa forma de manifestação do Diabo.

Ao utilizar esses dois pilares, a teoria da prosperidade e a guerra espiritual, Macedo construiu um império. O Bispo utiliza diversas formas para poder se comunicar com os fiéis, como a televisão, o rádio, os cultos e os livros.

O proselitismo em rádio e TV constitui o mais poderoso meio empregado pela Universal para atrair rapidamente grande número de indivíduos das mais diversas localidades geográficas à igreja. Por sua capacidade ímpar de introduzir a igreja, sua mensagem e seu apelo religioso nos lares, o evangelismo eletrônico apresenta a vantagem de poder alcançar aqueles que não possuem contato ou relação de confiança, amizade e parentesco com fiéis da denominação (MARIANO, 2004, p. 130).

A mensagem, em muitas oportunidades, apresenta duros ataques às religiões de matriz africana. $\mathrm{O}$ polêmico livro Orixás, Caboclos e Guias: Deuses ou Demônios? é exemplo dessa discussão. Devido ao conteúdo considerado intolerante, o livro (lançado originalmente em 1987) foi retirado liminarmente de circulação após decisão do Tribunal Regional Federal da $1^{\circ}$ Região, em 2005. A decisão foi tomada porque, segundo o Ministério Público Federal, a obra incitava a segregação religiosa e a intolerância às religiões afro-brasileiras. ${ }^{\text {xiii }}$ No mesmo ano, contudo, a $6^{\circ}$ Turma do TRF da $1^{\circ}$ Região decidiu pela continuidade de circulação da obra. O que, de fato, protegeu Macedo foi o direito de exercer a liberdade de expressão ${ }^{\text {xiv }}$ Para completar a polêmica, a editora Unipro lançou 800 mil cópias do livro, em 2019. ${ }^{\mathrm{xv}}$ Após a divulgação, entidades ligadas às religiões atingidas e diversos membros da sociedade civil criaram uma petição online com objetivo de impedir a venda e a circulação do livro. ${ }^{x v i}$ A petição contou com mais de 25 mil assinaturas.

No livro, Macedo transmite uma mensagem de caos e salvação. É uma guerra interminável entre Deus e o Diabo, onde os seres humanos precisam estar preparados para enfrentá-la.

O fato é que realmente tudo quanto existe de ruim neste mundo tem sua origem em satanás e seus demônios. São eles os causadores de todos os infortúnios que atingem o ser humano, direta ou indiretamente (MACEDO, 2019, p.119).

Essas criaturas são tratadas como deuses pelos adeptos das religiões de matriz africana (Umbanda, Quimbanda e Candomblé) e o Espiritismo.

Na realidade, orixás, caboclos e guias- sejam lá quem forem, tenham lá o nome mais bonito- não são deuses. Os exus, os pretos velhos, os espíritos de crianças, os caboclos ou os "santos" são espíritos malignos sem corpos, ansiando por acharem um meio para se expressarem neste mundo, não podendo fazê-lo antes de possuírem alguém (Ibidem, p.19).

Macedo elabora um cenário onde, desde o período colonial, as religiões de origem africana representam um espaço de atuação dos espíritos malignos. Essas religiões conseguiram se misturar com as 
práticas indígenas e, inclusive, católicas. Desde então, os adeptos são utilizado pelos demônios, espíritos malignos (cada espírito para uma ação específica) para, de acordo com o Bispo, levarem o mal ao mundo. As pessoas são possuídas, ficam doentes (e, mesmo diante procura médica, não conseguem obter a cura), perdem empregos, ficam pobres, perdem familiares e não conseguem encontrar soluções para os problemas do cotidiano devido à relação com os demônios e à religião. Em alguns casos, no mínimo estranhos, à relação também se faz presente para causar a destruição de pessoas inocentes.

Temos uma pessoa em nossa instituição que, no tempo em que frequentou o espiritismo, perdeu um filho com dezessete anos, porque, ao passar por uma encruzilhada, de um pontapé nas coisas ali arraiadas. Mil e um desastres automobistísticos têm acontecido nas encruzilhadas onde são colocados trabalhos de bruxaria. Existem demônios que se dizem responsáveis pelas encruzilhadas, e vivem à espreita dos que passem por ali, para deles se apossarem. (Ibidem, p. 50).

Essas possessões ocorrem, de acordo com o Bispo, de várias formas: hereditariedade, pela participação direta ou indireta com os centros espíritas, por trabalhos ou despachos, por maldade dos demônios, por envolvimento com pessoas que praticam o espiritismo, por comidas sacrificadas aos ídolos e por rejeitarem a Cristo. O exorcismo seria um caminho para conseguir livra-se da possessão. Macedo reforça a tese que os adeptos das religiões de matriz africana estão, na verdade, sendo manipulados pelos espíritos ruins e que precisam imediatamente se afastar dos terreiros. Ele apresenta exemplos de seguidores desesperados e desiludidos que conseguiram, após contato a IURD, uma solução para os problemas.

(...) essas pessoas encontraram em Jesus Cristo a única e verdadeira fonte de poder. Deram um basta a uma vida de opressão, cansaço e desilusão; quebraram os gongás, fecharam os terreiros, destruíram as imagens e os objetos fetichistas. Adquiriram uma bíblia, onde aprenderam que Deus condena a feitiçaria e proíbe a consulta aos espíritos que dizem ser de pessoas mortas. (Ibidem, p.21).

Em outro trecho, Edir Macedo agradece ao trabalho realizado por ex-pais e ex- mães de santo para a IURD.

Ficamos emocionados quando observamos ex-pais de santo, ou ex-mães de santo, ajudando-nos na libertação das pessoas que chegam diariamente até nós (Ibidem, p. 168).

Os casos mencionados podem, a meu ver, ser associados também a uma disputa por espaço dentro do campo religioso. Em outras palavras uma disputa por novos fiéis.

A hostilidade a estas religiões se deve, acima de tudo, ao fato de serem suas principais concorrentes no mercado de soluções simbólicas e prestação de serviços religiosos para os estratos mais pobres da população (MARIANO, 1995, p. 127). 
Como as respectivas religiões estão presentes em espaços sociais mais humildes ou conforme ORO (1997) aponta, onde os fiéis compartilham além do mesmo nível social dos mesmos códigos simbólicos e cognitivos, a disputa fica evidente. Ao obter sucesso nessa missão, a IURD fica cada vez mais cheia, mas as religiões de matriz africana estigmatizadas negativamente.

\section{As religiões de matriz africana}

A intolerância à cultura negra são rotineiras e, por consequência, é importante mencionar outro panorama sobre a história das religiões de origem africana no Brasil. A partir do período colonial até 1888, os negros oriundos do continente africano e, posteriormente, os nascidos no Brasil, foram obrigados a trabalharem em um regime desumano de escravidão. Os escravos representaram o grosso da mão de obra durante ciclos econômicos como do açúcar, do ouro e do café. (CUNHA, 2017, pag.77). Além do trabalho forçado, os escravos eram açoitados, eram mal alimentados e, dessa forma, tinham uma baixa perspectiva de vida.

A Igreja Católica foi um dos pilares desse processo. Não é novidade mencionar que o catolicismo representa importante papel na formação social e cultural do Brasil. A forma, contudo, dessa relação é marcada por diversas formas de violência. Um dos trabalhos dos missionários religiosos, conforme mencionado ao longo da pesquisa, era evangelizar os povos originários e, posteriormente, os escravos africanos. Esse trabalho servia para doutrinar os escravos, evitando eventuais fugas, formação de quilombos e manifestações. Os senhores proprietários eram responsáveis pela formação religiosa dos escravos, enquanto as diversas religiões africanas eram jogadas na clandestinidade. De acordo com VAINFAS (1986, p39) o processo de cristianização dos povos africanos começou nos portos africanos ou nos portos de desembarque dos negreiros com o uso do batismo e a mudança para um nome cristão. ( about CUNHA, 2017, p.86). Dessa maneira, ocorreram profundas transformações nos aspectos sociais e culturais dos africanos.

No Império, de acordo com o artigo $5^{\circ}$ da Carta Constitucional de 1824, a Igreja Apostólica Romana tornou-se a religião oficial do país. As demais religiões, perseguidas durante o período colonial, ganharam relativa liberdade, mas os cultos deveriam ser em âmbito doméstico. Os negros com objetivo de se livrarem da opressão do catolicismo adotavam a estratégia de fingir que rezavam para os santos católicos substituindo-os pelos orixás os quais, a seu ver, a eles correspondiam (SILVA, 2019, p.24).

O efeito prático de todo o aparato de inculcação do Catolicismo é desconhecido: impossível saber quantos escravos se converteram de fato à religião dominante. $\mathrm{O}$ Censo de 1872 tinha uma pergunta sobre a religião da população. O resultado é surpreendente, pois dos quase 10 milhões de habitantes do Império, naquele ano, 
1,5 milhão era de escravos, dos quais apenas $0,12 \%$ foram declarados não católicos. A população livre se declarou não católica em $0,33 \%$. Ou seja, pelos dados do Censo, os escravos eram proporcionalmente mais católicos do que os livres (CUNHA, 2017, p.93).

O cenário começou a mudar a partir da Proclamação da República (1889) e o decreto 119-A, de autoria de Rui Barbosa. Após diversos anos de luta e revindicações, o Estado começou a reconhecer a pluralidade da sociedade, garantindo a democracia e a laicidade. A discussão, é claro, apresenta um histórico complexo sobre os conceitos, à forma como foram, e ainda são, construídos em cada país e se, de fato, são respeitados. De acordo com GIUMBELLI (2008), o Brasil adotou a separação entre Estado e igrejas e de forma concreta garantiu a liberdade religiosa e da igualdade de grupos confessionais, o que daria legitimidade ao pluralismo religioso. O mesmo autor lembra que a Igreja Católica, que foi contra o projeto de separação, soube utilizar os aspectos da liberdade religiosa para recuperar sua presença no campo social como, por exemplo, com o retorno do ensino religioso em escolas públicas, no início da década de 1930. Ou seja, embora tenha ocorrido à separação entre Estado e religião, os privilégios católicos foram mantidos, principalmente a partir do governo Getúlio Vargas (1930-1945). ZYLBERSZTAJN (2012) aponta que a $1^{\circ}$ Constituição Republicana, de 1891, foi a mais explícita e contundente da história do Brasil no quesito separação entre Estado e religião. As constituições seguintes, contudo, retomaram alguns aspectos de cooperação com as religiões.

As religiões de matriz africana, em contrapartida, sofreram com o mesmo processo de exclusão e de violência. Essa perseguição, descriminação e preconceito ocorreram por vários motivos: política de embranquecimento e de modernização, e de discursos médicos como o sanitarista. ORO (2011) lembra que, neste contexto, as religiões eram facilmente enquadradas no Código Penal, nos artigos 156, que prevê o exercício ilegal da medicina; no 157, que condenava a prática de espiritismo e do charlatanismo, e no 158, que prevê a prática do curandeirismo. Após a Ditadura Militar, as discussões sobre laicidade, liberdade religiosa e intolerância ganharam ainda mais força. De acordo com CUNHA (2017), estamos presenciando uma Segunda Onda laica com a participação dos movimentos sociais.

Já não há um oponente dominante único, como a Igreja Católica no século XIX, mas um campo complexo, que abrange instituições religiosas interessadas de fato no Estado Laico, inclusive igrejas evangélicas, centros espíritas e terreiros afrobrasileiros (Ibidem, p.511).

Os adeptos das religiões de matriz africana conquistaram mais espaço na mídia, nos movimentos sociais e no campo político para revindicar a legitimidade da laicidade do Estado brasileiro e o direito de exercer a crença. 
Art. 5, VI- é inviolável a liberdade de consciência e de crença, sendo asssegurado, o livre exercício dos cultos religiosos e garantida, na forma da lei, a proteção aos locais de culto e suas liturgias (BRASIL, 1988).

Porém, conforme apresentado, os neopentecostais foram os que mais cresceram no atual período. No campo político, por exemplo, é notória a presença de Bispos, pastores e deputados (ligados a Frente Parlamentar Evangélica) pautando as eleições presidências. O presidente eleito, Jair Bolsonaro, tem uma ampla relação com os neopentecostais. Ao longo da campanha, recebeu apoio do Pastor Silas Malafaia, da Assembleia de Deus Vitória em Cristo, e do Bispo Edir Macedo, da IURD, uma das figuras centrais da presente pesquisa. ${ }^{\text {xvii }}$

A história republicana apresenta uma relação controversa em relação à laicidade e a liberdade religiosa e de culto. A Igreja Católica (e os neopentecostais) e o Estado brasileiro com seus históricos de perseguição e preconceito contribuíram para construir um imaginário social desqualificador das religiões de matriz africana.

Tais procedimentos resultam, em grande medida, de representações depreciativas que, ao longo do tempo, foram construídas no Ocidente, e no Brasil, sobre as etnias e as culturas africanas, tidas como "primitivas" e "arcaicas", destinadas, portanto, a desaparecerem porque representavam o passado da humanidade (ORO, 2011. p. 227-228).

O Prof ${ }^{\circ}$. Dr ${ }^{\circ}$ Babalawô Ivanir dos Santos aponta que a liberdade religiosa não funciona para todos. Infelizmente, mesmo garantindo por lei, a liberdade religiosa e a liberdade de culto não são uma realidade para todas as religiões em solo brasileiro. Prova disso é que, nos últimos anos, assistimos um crescimento significativo de casos de intolerância religiosa no Brasil (SILVA, 2019, p.4)

Isso demonstra que a libertação do povo negro não foi realizada de forma completa. O sistema apresenta adaptações do período escravagista, levando ao genocídio da população negra, o aumento da população carcerária (normalmente associado aos jovens negros e pobres), ataques aos costumes, dificuldade de acesso a bens básicos como a saúde, à educação e ao lazer. Em relação à religião é possível observar ataques a terreiros e aos símbolos religiosos.

Impõe-se a sublinhar que as manifestações de intolerância religiosa contra as religiões de matriz africana, em particular, exibem altas doses de ódio e violência física e simbólica, o que potencializa o sofrimento dos que insistem em exercitar o seu direito humano e constitucional à liberdade de culto e crença (Ibidem, p.12).

O Guia de Luta contra a Intolerância Religiosa e o Racismo, organizado pelo CEAP (Centro de Articulação de Populações Marginalizadas) apresenta diversos casos emblemáticos na história recente do Brasil, como a depredação de estátuas na Praça dos Orixás, em Brasília; ataques a templos no Rio de Janeiro; insultos (macumbeiro safado) devido a práticas religiosas no Rio de Janeiro; um juiz que declarou 
que o Candomblé e a Umbanda não são religiões; e uma menina, de 11 anos de idade, que após sair de uma festa de Candomblé, levou uma pedrada na cabeça por homens que, na ocasião, portavam uma bíblia. Outro caso emblemático ocorreu no final nos anos 90 e início dos anos 2000, quando Mãe Gilda (Yalorixá Gildásia dos Santos) teve sua foto exposta em uma matéria do Jornal Folha Universal da IURD, onde afirmava que, no Brasil, estava em crescimento um "mercado de enganação" de "macumbeiros charlatões". Sendo que, dois meses antes, o seu templo foi invadido e depredado por adeptos de outra denominação evangélica, a Deus é Amor. Ao não resistir tamanha pressão, Mãe Gilda faleceu. A IURD foi condenada em primeira instância a indenizar a família de Mãe Gilda. É importante lembrar que o falecimento de Mãe Gilda ficou marcado na história do país, e data do falecimento (21 de janeiro de 2000), passou a ser conhecido como o Dia Internacional de Combate à Intolerância Religiosa. (SILVA, 2019, p.13-14).

Em outro campo importante de discussão, a educação, a intolerância também se mostra presente. Em uma pesquisa que realizei sobre o ensino religioso em escolas públicas na cidade de Porto Alegre foi possível obervar a ineficácia dos modelos em oferecer um conteúdo sobre a história cultural religiosa de matriz africana. ${ }^{\text {xviii }}$ Embora nos últimos anos a discussão sobre diversidade cultural e social tenha adquirido força neste campo, diversos obstáculos surgem para o avanço da temática nas escolas. É curioso que, enquanto isso, a legitimidade do ensino religioso em escolas públicas é cada vez mais forte. Dessa forma é valioso o trabalho de OLIVEIRA (2014) que, ao aproveitar a presença da disciplina nas escolas e a lei $\mathrm{n}^{\circ}$ 10.639 (BRASIL, 2003) $^{\text {xix }}$ que passa a incluir oficialmente na rede de ensino a obrigatoriedade da temática "História e Cultura Afro-Brasileira" (ZANIRATI, 2018, p.20), questiona o porquê as temáticas de origem africana ainda ficam de fora dos conteúdos. Não seria o momento de utilizar esse espaço para debater intolerância religiosa? O autor alertar que as questões que se referem às religiões afro-brasileiras, por exemplo, também se mostram relevantes para um entendimento do que é o Brasil (OLIVEIRA, 2014, p.177).

Ao longo do trabalho de campo em Porto Alegre, os professores admitiram a dificuldade de tratar o tema, muitas vezes pela pouca familiaridade sobre o assunto, mas também devido a possível reação negativa dos pais ou responsáveis dos alunos. Uma professora alertou que os alunos pertencentes às religiões de matriz africana dificilmente se manifestam sobre assunto. A presença de alunos de religiões neopentecostais em sala de aula poderia ser um dos motivos do silêncio.

Em suma, o Brasil ainda demonstra dificuldades em atender os indivíduos de todas as classes, raças, religiões e etc. Existem hierarquias fortemente marcadas por um passado colonialista e escravagista. Por este motivo quando a população negra usufrui aos mesmos direitos da classe média e branca do Brasil gera incômodo. A discussão, que envolve o etnocentrismo, também é sobre classes. 


\section{Considerações finais}

O objetivo da pesquisa foi apresentar como foi, e ainda é, construindo o discurso etnocêntrico da Igreja Universal, de Edir Macedo, contra as religiões de matriz africana. O etnocentrismo representou um dos pilares das grandes potências capitalistas em levar "civilização", ou como se fala atualmente "democracia", para os "selvagens" ou "atrasados". Quais os efeitos desse sistema? No Brasil, por exemplo, após mais de três séculos de escravidão, vivemos num período democrático, com leis que protegem os direitos da população, inclusive nos aspectos religiosos. Porém, na prática, a realidade é diferente. O Guia de Luta contra a Intolerância Religiosa e o Racismo aponta que embora a Constituição seja um importante mecanismo de proteção às minorias, apenas palavras não são capazes de mudar a realidade da sociedade, isto é, não basta falar que o Brasil é um país laico e democrático.

Se, desde a Proclamação da República, o Estado brasileiro não tem mais religião oficial; se a Constituição de 1988 sinalizou enfaticamente para a liberdade de religião; se a vocação da sociedade brasileira parece ser o ecumenismo religioso, não têm cabimento em nosso país as manifestações de intolerância religiosa, inclusive com uso da violência, registradas cada vez mais com frequência (SLVA, 2019, p.24).

A IURD atua diante as falhas do sistema. O Bispo Edir Macedo soube aproveitar este cenário para construir uma guerra espiritual e mercadológica em busca de vários objetivos, entre eles "salvar" a vida dos adeptos das religiões de matriz-africana, que estão sendo enganados e manipulados por uma cultura “atrasada" e "primitiva". Macedo precisa de um país (na verdade um mundo, afinal de contas a IURD está presente em centenas de países) racista, intolerante e desigual para que o discurso tenha efeito. Por este motivo ocorre o etnocentrismo contra as culturas de origem africana. E devido à imensa popularidade e importância no mundo, o Bispo é responsável direito pela expansão da intolerância religiosa e a violência. Ou seja, além de se alimentar dessa realidade, ele alimenta os milhões de seguidores.

O que fazer diante essa situação? O sentimento de estranhamento a uma determinada cultura, ou até mesmo a diferentes hábitos de outra pessoa, é um processo natural. Porém, temos a missão de impedir que esse estranhamento se transforme em qualquer sentimento de superioridade ou de repulsa ao outro. As instituições (teoricamente laica) tem que estar preparadas para assumirem essa responsabilidade e apresentarem, ao lado da sociedade civil e dos movimentos sociais, uma verdadeira luta antiopressão para que possamos viver em uma sociedade justa, respeitando todas as diferenças. É necessário trabalhar para que a punição não seja o único caminho para evitar as práticas intolerantes, pois embora possa, de forma imediata, ser a única opção, ela não atua na raiz do problema. É preciso, ao longo prazo, algo realmente eficiente. Um dos caminhos é justamente reconhecer que vivemos em uma sociedade racista e intolerante, a partir do reconhecimento da cultura negra no Brasil (como o preconceito foi construído e como o sistema 
neoliberal ainda se alimenta dele) e, acima de tudo, que qualquer minoria oprimida possa ter espaço e voz para poder reivindicar os direitos. Nesse cenário, devemos estar preparados para escutar. Penso que um trabalho de base nas escolas possa ser eficiente para romper as barreiras do preconceito, pois é o momento onde os jovens estudantes se afastam de casa, da realidade familiar e começam a conviver com as diferenças. Diferenças que vão estar presentes ao longo da vida.

Por fim, são comuns discursos de combate aos evangélicos com objetivo de defender a laicidade, os direitos das mulheres e da comunidade LGBTTT e acabar com a intolerância religiosa e o preconceito no país. Porém é importante deixar claro: Edir Macedo, Silas Malafaia e a Frente Parlamentar Evangélica, embora de grande influência, não representam a totalidade dos evangélicos no Brasil. Esse grupo realmente ataca a laicidade do Estado e as políticas progressistas, produzindo um discurso de ódio e de intolerância. Devem ser combatidos. Os evangélicos, contudo, são heterogêneos. Existem grupos progressistas. Existem grupos sem formação política. Existem grupos completamente abandonados pelo Estado. É inegável que ao estarem presentes em diversos cantos do país, as igrejas neopentecostais conseguem aproveitar esse espaço e atuam frente ao desamparo social. Muitas pessoas encontram na Igreja certo conforto. Em artigo publicado pelo Intercept Brasil, Rosana Pinheiro-Machado aponta que, durante a crise do coronavírus, as igrejas evangélicas se fizeram presentes como agentes centrais nas comunidades mais vulneráveis do Brasil oferecendo conforto e alguma ajuda assistencial, como doações de cestas básicas ${ }^{\mathrm{xx}}$. É preciso, dessa maneira, entender a realidade do "outro" (os evangélicos). Muitos evangélicos, que buscam uma vida digna, são estigmatizados de "alienados", "ignorantes" e "intolerantes". Em suma, se a nossa missão é lutar por uma sociedade justa e sem preconceito, creio que precisamos de uma tática diferente que "combater todos os evangélicos". Precisamos, na verdade, preencher esse espaço, conquistar as pessoas, apresentar cenários alternativos e, de fato, combater o próprio sistema que causa essa realidade desigual e brutal. Se pretendermos realizar alguma mudança na sociedade, os evangélicos (os cristãos, de modo geral), que correspondem à maioria da população brasileira, devem fazer parte dessa luta.

\section{Referências}

BRASIL. Art. 5 da Constituição Politica do Imperio do Brazil (25 de março de 1824). Disponível em < http://www.planalto.gov.br/ccivil_03/Constituicao/Constituicao24.htm>. Acesso: 17 abril. 2020.

BRASIL. Art. 5 da Constituição da República Federativa do Brasil. (05 de Outubro de 1988). Disponível em < https://www.senado.leg.br/atividade/const/con1988/CON1988_05.10.1988/art_5_asp>. Acesso: 17 abril. 2020.

CARDOSO DE OLIVERIA, Roberto. O trabalho do antropólogo. Cap.1 O trabalho do antropólogo: olhar, ouvir e escrever, p. 17-37. Editoras Unesp e Pararelo 15. 2000.

CASTRO, Celso. Evolucionismo Cultural textos de Morgan, Tylor e Frazer. Editora Zahar. $2^{\circ}$ edição. 2005. 
CASTRO, Celso. Franz Boas. Antropolgia Cultural. Editora Zahar. 2005.

CUNHA, Luiz Antônio. A educação brasileira na primeira onda laica: do Império a República. Edição do autor. 2017.

DAMATTA, Roberto. Relativizando Uma introdução à antropologia social. Editora Rocco LTDA $5^{\circ}$ edição. 1997.

GIUMBELLI, Emerson. A presença do religioso no espaço público: modalidades do Brasil. Religião e Sociedade, Rio de Janeiro, v.28, n-2, p.80-101.

LAPLANTINE, François. Aprender Antropologia. Editora brasiliense. $15^{\circ}$ edição. 2003

LARAIA, Roque de Barros. Cultura um conceito antropológico. Jorge Zahar Editor. 14 Edição. 2001.

MACEDO, Edir. Orixás, Caboclos e Guias. Deuses ou Demônios? Editora Unipro $18^{\circ}$ Edição. 2019.

MARIANO, Ricardo. Igreja Universal do Reino de Deus: a magia institucionalizada. Revista USP, São Paulo, setembro/dezembro 1996.

MARIANO, Ricardo. A Expansão pentecostal no Brasil: o caso da Igreja Universal. Estudos avançados. 2004.

MENESES, Paulo. Revista SymposiuM, ano 3, Número especial, 1999.

OLIVEIRA, Amurabi. A vez das religiões afro-brasileiras no ensino religioso? As possibilidades e limites abertos pela lei n. ${ }^{\circ}$ 10.639/03. Revista de Estudos e de Pesquisa da Religião, Juiz de Fora, v. 17, n. 1, p. 171-188, 2014.

ORO, Ari Pedro. A laicidade no Brasil e no Ocidente. Algumas considerações. Civitas - Revista de Ciências Sociais, v. 11, n 2, p. 221-237, 2011.

ORO, Ari Pedro. Neopentecostais e afro-brasileiros: quem vencerá esta guerra? Debates do Ner, v. 1, n. 1, p. 10-36, 1997.

ROCHA, Everardo P. Guimarães. O que é etnocentrismo. Editora brasiliense. 1988

SILVA, Jorge da. Guia de Luta contra a Intolerância Religiosa e o Racismo. Organização: Centro de Articulação de Populações Marginalizadas (CEAP) e $\operatorname{Prof}^{\circ}$. Dr ${ }^{\circ}$ Babalawô Ivanir dos Santos. Coordenação Editoral: $\operatorname{Prof}^{\circ}$. Dr $^{\circ}$ Babalawô Ivanir dos Santos, $2^{\circ}$ Edição, 2019.

SOUZA, Etiane Caloy Bovkalovski. A Imagem do Diabo nos livros de Edir Macedo da Igreja Universal do Reino de Deus. Dissertação apresentada como requisito parcial à obtenção do grau de mestre. Curso de Pós-Graduação em História, Setor de Ciências Humanas, Letras e Artes, Universidade Federal do Paraná. 2000

ZANIRATI, Giovani. Ensino Religioso em escolas públicas de Porto Alegre: Modelos gerais e práticas específicas. Monografia de Bacharelado em Ciências Sociais, Universidade Federal do Rio Grande do Sul. 2018.

ZYLBERSZTAJN, Joana. O princípio da laicidade na Constituição de 1988. Tese de Doutorado. São Paulo: Faculdade de Direito da Universidade de São Paulo, 2012.

Recebido em: 29/04/2020.

Revisto em: 08/06/2020.

Aceito em: 04/08/2020. 


\section{Notas}

${ }^{\text {i } G r a d u a d o ~ e m ~ C i e ̂ n c i a s ~ S o c i a i s ~ p e l a ~ U n i v e r s i d a d e ~ F e d e r a l ~ d o ~ R i o ~ G r a n d e ~ d o ~ S u l . ~ E-m a i l: ~ g i o v a n i 1789 @ h o t m a i l . c o m . ~ O R C I D: ~}$ https://orcid.org/0000-0002-6994-7652.

ii Disponível em: <https://noticias.uol.com.br/politica/ultimas-noticias/2020/01/23/indio-ta-evoluindo-cada-vez-mais-e-serhumano-igual-a-nos-diz-bolsonaro.htm> Acesso em: 20 fev. 2020.

iii Disponível em: <https://www.cartacapital.com.br/politica/bolsonaro-diz-que-indio-esta-evoluindo-e-se-tornando-humanoigual-a-nos/> Acesso em: 20 fev. 2020.

${ }^{\text {iv }}$ Disponível em: <https://veja.abril.com.br/brasil/bolsonaro-e-acusado-de-racismo-por-frase-em-palestra-na-hebraica/> Acesso em 20 fev. 2020.

v Disponível em: <https://blogdosakamoto.blogosfera.uol.com.br/2018/12/17/raposa-serra-do-sol-bolsonaro-mandou-indiocomer-capim-em-debate-de-2008/> Acesso em 20 fev. 2020.

${ }^{v i}$ É importante ressaltar que, mesmo diante as críticas contundentes, a escola evolucionista apresentou, o que pode ser entendido, como as sementes do relativismo cultural dentro da disciplina. Porque a disciplina, diferentemente das concepções adotadas por filósofos e missionários dos séculos anteriores, considerava o "outro" como um ser humano pertencente a uma sociedade, como o ocidental. A diferença, é claro, parte da concepção de hierarquias entre as sociedades, mas o "outro" deixava de ser "selvagem" e "inumano" para se tornar um indivíduo "atrasado". Além disso, um dos principais antropólogos da escola, Lewis Morgan, serviu de referência para grandes nomes das ciências humanas como Karl Marx, Friedrich Engels e Lévi-Strauss.

vii O pentecostalismo é oriundo da Reforma Protestante, movimento que rompeu com a unidade do cristianismo, no século XVI. O movimento apresentou diversas vertentes entre ela o protestantismo nascido nos Estados Unidos, que serviu de referência para o Brasil.

viii As três ondas do pentecostalismo no Brasil podem ser considerados como movimentos próprios, mas existe ao mesmo tempo uma importante ligação entre ela. A $1^{\circ}$ Onda ou pentecostalismo clássico, surgida nas primeiras décadas do século XX, apresenta uma característica anticatólica e a ênfase no batismo no Espírito Santo, o dom de falar em línguas em glossolalia; a $2^{\circ}$ Onda ou pentecostalismo neoclássico apresenta um rompimento com o conservadorismo da $1^{\circ}$ Onda, concedendo um pouco mais de liberdade ao fiel, fortalecida pelo trabalho da Igreja Internacional do Evangelho Quadrangular (International Church of The Foursquare Gospel), a partir da década de 50 . O uso do rádio para a difusão do evangelho serviu de referência a $3^{\circ}$ Onda, o neopentecostalismo.

ix Disponível em:<https://censo2010.ibge.gov.br/noticias-censo?id=3\&idnoticia=2170\&view=noticia $>$ Acesso em: 10 mar.2020.

x Disponível em; < https://g1.globo.com/politica/noticia/2020/01/13/50percent-dos-brasileiros-sao-catolicos-31percentevangelicos-e-10percent-nao-tem-religiao-diz-datafolha.ghtml> Acesso em: 10mar.2020.

xi Edir Bezerra Macedo nasceu no Rio de Janeiro, em 1945, em uma família de católicos. Ele passou, além do catolicismo, pela Umbanda, antes de ingressar no mundo pentecostal. Ele frequentou e permaneceu na igreja Nova Vida entre 1963 até 1975 até fundar a Igreja Universal do Reino de Deus (IURD).

xii Disponível em: < https://www.pragmatismopolitico.com.br/2020/03/bispo-edir-macedo-diz-que-coronavirus-e-inofensivo-eculpa-satanas-e-a-midia.html> Acesso: 12 mar.2020.

xiii Disponível em: < https://www.conjur.com.br/2005-dez-07/edir_macedo_nao_vender_livro_decide_trf-1> Acesso: 12 mar. 2020.

xiv Disponível em: 〈https://expresso-noticia.jusbrasil.com.br/noticias/136368/trf-libera-circulacao-do-livro-de-edir-macedo> Acesso: 12 mar. 2020.

${ }^{x v}$ Disponível em: 〈https://www.gospelprime.com.br/orixas-caboclos-e-guias-deuses-ou-demonios-edir-macedo/> Acesso: 12 mar.2020. 
xvi Disponível em: <https://revistaforum.com.br/brasil/igreja-universal-relanca-livro-que-trata-religioes-afro-brasileiras-comodemoniacas/> Acesso:12 de mar. 2020.

xvii A própria figura política de Jair Bolsonaro ganhou muita força após construir uma aliança com a Frente Parlamentar Evangélica, entre os anos 2010 e 2011. Na época, após a vitória de Dilma Rousself (PT) à presidência da República, lideranças evangélicas decidiram atuar para barrar projetos progressistas voltados principalmente a comunidade LGBT. Em 2011, Bolsonaro manifestou-se contra o projeto Escola sem Homofobia (ficou conhecido como kit gay) do governo Dilma, que seria distribuído nas escolas públicas. Para Bolsonaro o material tinha um conteúdo que incentivava a sexualidade precoce e a homossexualidade. A FPE comprou a briga com Bolsonaro e decidiu articular uma campanha contra o material e o governo federal. O material, por fim, foi vetado por Dilma.

xviii Atualmente dois tipos de modelos são propostos: o confessional ( os estudantes são separados de acordo com a religão) e o não confessional que, na verdade, apresenta diversas nomenclaturas ( um conteúdo universal sobre a religião). Porém, muitas escolas abordam um material próprio, tentando se afastar do campo religioso.

xix Lei n. ${ }^{\circ} 10.639$, de 9 de janeiro de 2003. Altera a Lei n ${ }^{\circ} 9.394$, de 20 de dezembro de 1996, que estabelece as diretrizes e bases da educação nacional, para incluir no currículo oficial da Rede de Ensino a obrigatoriedade da temática "História e Cultura AfroBrasileira", e dá outras províncias. Disponível em: $<$ http://www.planalto.gov.br/ccivil_03/Leis/2003/L10.639.htm>. Acesso: 20 abril. 2020.

${ }^{\text {xx }}$ Disponível em :<https://theintercept.com/2020/04/14/coronavirus-igrejas-evangelicas/?comments=1>Acesso: 20 abril. 2020. 